This item was submitted to Loughborough's Research Repository by the author.

Items in Figshare are protected by copyright, with all rights reserved, unless otherwise indicated.

\title{
Absorptive capacity and market orientation in public service provision
}

PLEASE CITE THE PUBLISHED VERSION

http://dx.doi.org/10.1080/0965254X.2011.643915

PUBLISHER

(c) Taylor and Francis

VERSION

AM (Accepted Manuscript)

LICENCE

CC BY-NC-ND 4.0

REPOSITORY RECORD

Hodgkinson, lan R., Paul Hughes, and Mathew Hughes. 2019. "Absorptive Capacity and Market Orientation in Public Service Provision”. figshare. https://hdl.handle.net/2134/14769. 
This item was submitted to Loughborough's Institutional Repository (https://dspace.lboro.ac.uk/) by the author and is made available under the following Creative Commons Licence conditions.

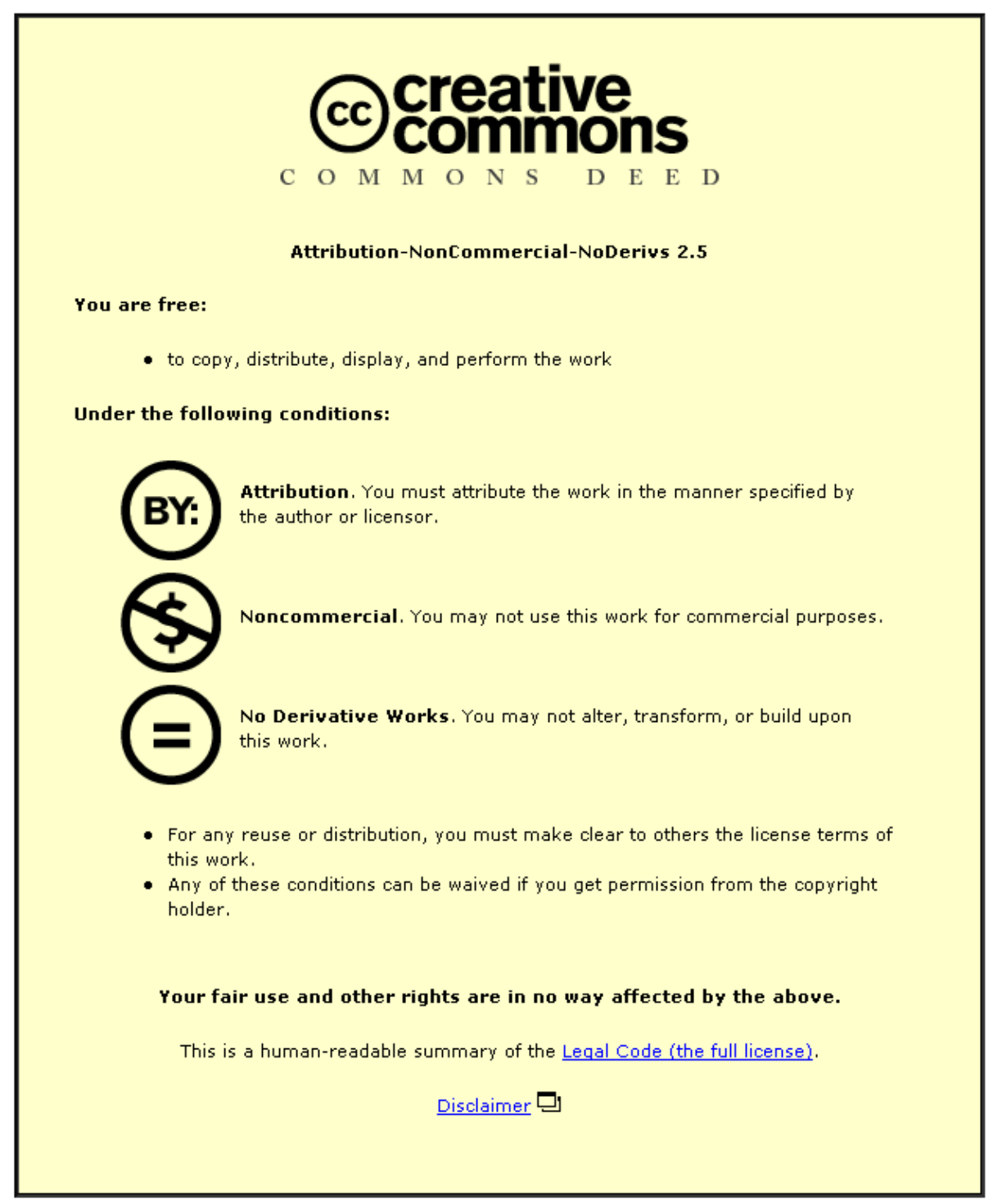

For the full text of this licence, please go to: http://creativecommons.org/licenses/by-nc-nd/2.5/ 


\section{Absorptive Capacity and Market Orientation in Public Service Provision}

\section{Ian R. Hodgkinson}

School of Business and Economics, Loughborough University, Loughborough, United Kingdom.

\section{Paul Hughes}

School of Business and Economics, Loughborough University, Loughborough, United Kingdom.

\section{Mathew Hughes}

Nottingham University Business School, University of Nottingham, Nottingham, United Kingdom.

This is an Author's Original Manuscript of an article whose final and definitive form, the Version of Record, has been published in the Journal of Strategic Marketing 2012 [copyright Taylor \& Francis], available online at: http://www.tandfonline.com/doi/abs/10.1080/0965254X.2011.643915 


\section{Absorptive Capacity and Market Orientation in Public Service Provision}

The application of market orientation to public organisations does not adequately account for the unique features of this context. Drawing on absorptive capacity literature, this is the first study to examine the role of organisation's learning environment on the market orientation-performance interface for two opposing public management contexts. The research involved a national survey questionnaire to 1,060 internal and external public leisure service providers in England. Empirical testing through structural equation modelling revealed that not all dimensions of market orientation are universally positive and marketing scholars should seek to examine and understand market orientation in the context of the organisation and its learning mechanisms, as absorptive capacity has clear and different moderation effects under different management contexts.

Keywords: absorptive capacity; market orientation; public service; leisure providers

\section{Introduction}

The need to study the market orientation construct in public organisations and gather empirical evidence on its effects in these organisations has been widely recognised (Cervera, Molla, \& Sanchez, 2001; Macedo \& Pinho, 2006). However, efforts to do so are deficient on two grounds. First, while public service provision is increasingly mindful of meeting the expressed demands of its customer users, and to an extent in finding out their unexpressed needs, some aspects of public service provision are historically outward-facing owing to their close interface with customers, for example, public leisure provision. But public leisure provision is differentiated on the basis that it can be managed in alternative ways. Thus, the study of marketing principles across internal and external management contexts in public leisure provision is necessary to test the robustness of the market orientation construct with respect to more effectively managing this public service. The value of market orientation for public organisations has received a burst of scholarly examination (Cano \& Sams, 2009; Shoham, Ruvio, Vigoda-Gadot, \& 
Schwabsky, 2006), but so far studies have failed to adequately account for the unique features of this context. Accordingly, a test of the robustness of the direct relationship between market orientation and customer performance in the public leisure domain requires the management context to be accounted for. Addressing this gap then enables a more acute contribution to marketing theory to be made.

Second, the theory that organisations collect intelligence on customers, disseminate this intelligence organisation-wide and respond to this intelligence in turn accrue superior returns to customer performance that are sustainable over time, does not account for learning processes that maintain and augment these performance discrepancies. An organisation's absorptive capacity can help to explain persistent differences among organisations in profiting from externally acquired knowledge (Lichtenthaler, 2009). Absorptive capacity represents an organisational capability to utilise prior related knowledge to recognise the value of new information, assimilate it, and transform externally acquired intelligence (for example, the intelligence acquired through the organisation's market orientation) into learning artefacts maintained in organisational memory that can then be applied to commercial ends (Cohen \& Levinthal, 1990; Huber, 1991; Jansen, Van Den Bosch, \& Volberda, 2005; Lane, Koka, \& Pathak, 2006; Zahra \& George, 2002). In theory, then, the returns to market orientation would likely be moderated by the absorptive capacity of the organisation.

Studies into marketing-led organisations have reported advantages to those with a capable absorptive capacity (Chen, Lin, \& Chang, 2009). Studies have also reported on the moderating effects of absorptive capacity on the relationship between market sourcing strategy and performance (Murray, Kotabe, \& Westjohn, 2009), and others have explored 
the relevance of absorptive capacity to marketing efforts when organisations experience a rapid rate of knowledge obsolescence (Narasimhan, Rajiv, \& Dutta, 2006). More pertinent to this study, Jones and Hecker (2003) introduce absorptive capacity as a compatible and more insightful theory to market orientation; while McDonald and Madhavaram (2007) present an integrated discussion of the role of prior knowledge in market orientation. However, the impact of absorptive capacity on the market orientationperformance interface across public management contexts is yet to be empirically tested.

This study contributes to marketing theory in two important ways. First, and to the best of our knowledge, this is the first study to account for the effect of market orientation on the customer performance of public service organisations while simultaneously accounting for internal and external management arrangements. In this respect, the study contributes new evidence to expand the relevance of this key marketing theory to public service management. Second, and to the best of our knowledge, this is the first study to empirically test the role of organisations’ absorptive capacity in benefiting from market orientation across management context. Marketing research has so far neglected the implications of absorptive capacity to both benefiting from market orientation and sustaining exclusive returns from market orientation in opposing public management contexts. We contribute to the theoretical and empirical development of market orientation by addressing this neglect.

\section{The Management of Public Leisure Services}

In this study a public leisure service refers to a publicly-owned site, with at least one of the following facilities; health \& fitness suite, swimming pool, or sports hall, where at 
least one is available to members of the general public on a pay and play or membership basis. Internal service providers are the traditional vehicle for managing public services and still dominate public leisure provision in the UK (Audit Commission, 2006). Within internal service provision, local government take full responsibility for income, expenditure, pricing and programming, and is accountable for all risks involved. External service providers, on the other hand, are a response from local government to a changing environment, particularly in resisting financial pressures (Reid, 2003). In turn, local government enters into a performance-management contract, where the private or third sector manages the service as an agent of the local government. The concept of 'partnership' is increasingly promoted as an ideal model for public sector management (Friend, 2006; Peters, 1998) and a chief policy response to a range of political ills, such as the reduction of inefficiencies in service delivery.

The key differences between internal and external providers to service provision are linked to the complexity of the managerial structures and organisational mechanisms of each provider. Internal providers are notoriously bureaucratic comprising many formal routines, mechanistic structures, complicated communication channels, many external stakeholders, conflicting environmental demands, and low managerial autonomy (e.g., Brewer \& Lam, 2009). Alternatively, external providers bring private sector management expertise, experience and ideas to the public sector service provision and enable local governments to reshape the structure and composition of service delivery, enhancing knowledge flows by instigating partnerships that recombine existing social and knowledge resources in new ways (McDermott, Corredoira, \& Kruse, 2009). This crossfunctionality across public-private boundaries requires coordination mechanisms to 
instigate a process that recombines the resources and information of better-placed actors with local government and in turn fosters multiplex, cross-cutting ties among previously isolated public, voluntary and private actors in turn; thus improving access to a variety of knowledge resources as an outcome.

\section{Market Orientation in the Public Service Sector}

Butler and Collins (1995), Caruana, Ramaseshan and Ewing (1999), and

Crompton (2008) suggest that the broad principles of the marketing concept are applicable to public service agencies; this includes existing conceptualisations, frameworks and models which can be suitably adapted for the operating environment of public sector organisations (Butler \& Collins, 1995). This approach suggests that there is no need for a fundamental redefinition of marketing. Rather there is simply a need to adapt the core concepts of marketing to reflect the specific context and characteristics of public services (Laing, 2003). This is underpinned by the contention that “...there are very few inherently public services, as evidenced by the creeping privatisation of many such public services, raising the question of whether in fact many public services can be viewed as fundamentally different or unique” (Laing, 2003, p. 430).

Marketing has historically paid little attention to its applications in public organisations and public service providers (Cervera et al., 2001; Macedo \& Pinho, 2006). However, many leisure service administrators have looked to the private sector for inspiration, implementing marketing principles and practices as a response to increasing political emphasis on service efficiency and effectiveness (Navatorov \& Crompton, 2001). Customer expectations of public leisure services have also changed over the 
decades, whereby service users are now increasingly appraising leisure services against private sector competitors (Laffin \& Liddle, 2006). The notion of citizens as customers is gradually gaining credence in practice (Caemmerer \& Banerjee, 2009), within this context the application of marketing tools is a means to more effectively satisfy customer expectations (Cervera et al., 2001). The marketing concept is the philosophical foundation of a market orientation (Jaworski \& Kohli, 1993), which is defined as “...the organisation-wide generation of market intelligence pertaining to current and future customer needs, dissemination of the intelligence across departments, and organisationwide responsiveness to it” (Kohli \& Jaworski, 1990, p. 6). Crompton (2008) argues that a market orientation is appropriate for public service agencies because the application of a market orientation is determined by the mission and objectives being pursued, whether in a business or public service context. Caruana et al. (1999) confirm that a market orientation is a worthwhile management principle to pursue in the public sector. Moreover, public leisure service providers can benefit from marketing-based strategies to inform the commercialisation of their services (Shoham et al., 2006) in response to the current local government environment of budget cuts (Berg, Barry, \& Chandler, 2008). Arguably, market orientation can provide public services with suitable instruments to acquire knowledge of public needs and help service delivery to better satisfy those needs (Cervera et al., 2001). The adoption of a market orientation by leisure providers may then facilitate the provision of better services more suitable to citizens' demands.

\section{Market Orientation and Absorptive Capacity}


Empirical research reports positive linkages between measures of market orientation and performance (Kirca et al., 2005; Jaworski \& Kohli , 1993; Narver \& Slater, 1990; Nelson \& Henderson, 2005; Olavarrieta \& Friedmann, 2008). However, studies have also shown that a direct test of the relationship incompletely accounts for how market orientation can create sustainably superior performance (Baker \& Sinkula, 2005; Day, 1999), suggesting that moderating effects exist (Langerak, 2003). We propose an organisation's absorptive capacity to represent one such moderating factor.

Dickson (1996) and Baker and Sinkula (1999) suggest that sustainable superior customer performance cannot accrue from the market information possessing behaviours that accompany the implementation of a strong market orientation alone as these behaviours can be readily copied. Rather, the learning environment that organises and translates externally-acquired knowledge is what shapes a sustainable advantage capable of generating long-term superior performance (Baker \& Sinkula, 1999).

An organisation's absorptive capacity defines the nature of the organisation's learning environment (Cohen \& Levinthal, 1990; Lichtenthaler, 2009). A superior capability to organise, assimilate and transform externally-acquired knowledge obtained through market orientation behaviours should leverage the effect of market orientation on customer performance. An organisation’s absorptive capacity represents one such capability in this respect (Cohen \& Levinthal, 1990; Jansen et al., 2005).

The simple acquisition of knowledge begins the organisational learning process. However, knowledge acquisition does not lead inevitably to successful knowledge application (Lichtenhaler, 2009). The routines within the firm to organise and value acquired knowledge in a way that embellishes and refreshes lessons from the past (e.g., 
prior knowledge stocks), enable the transformation and bundling of knowledge into organisational learning in a form that can increase performance (Argote, McEvily, \& Reagans, 2003; Garud \& Nayyar, 1994; Kogut \& Zander, 1992; Walsh \& Ungson, 1991). As a learning process focused on knowledge acquisition (Grewal \& Tansuhaj, 2001) market orientation should benefit from absorptive capacity. By having in place an absorptive capacity to assimilate, organise, value and transform market knowledge acquired from its market orientation behaviours, an organisation should be better placed to respond more effectively and more quickly to market information, outperforming its competitors in turn (Baker \& Sinkula, 1999).

Research addressing absorptive capacity has not shown whether its effects differ by the complexity or otherwise of management context. However, studies into potential versus realised absorptive capacity have suggested that complex structures with an emphasis on routines and formalisation can harm the effectiveness of absorptive capacity whereas those with cross-functional interfaces emphasising connectedness and socialisation experience the opposite (Jansen et al., 2005). Marketing studies into the effectiveness of absorptive capacity also highlight the influence of organisational context (Yeoh, 2009). But these studies report on the effectiveness of absorptive capacity in terms of its development, not in terms of its payoffs. Information-laden organisations (i.e., those with market orientation) with complex structures would be expected to see their information transfer compromised by their inability to manage information adequately (Ocasio, 1997; Souchon et al., 2004; Vyas \& Souchon, 2003). Thus, the value of absorptive capacity may well differ by management context. 


\section{Hypotheses}

Customer needs and expectations continually evolve over time, as illustrated by increasing customer expectations of public services (Laffin \& Liddle, 2006). Market orientation through generating and disseminating market intelligence then ought to increase the scope, accuracy and relevance of the response to customers.

Market intelligence in this context is a broad concept which includes a consideration of exogenous market factors which affect customer and community needs, performance, and current as well as future needs of customers (Pitt, Caruana, \& Berthon, 1996). The generation of market intelligence is conducted collectively by individuals and departments throughout an organisation which enhances the development of long-term strategic objectives with the desire to satisfy customers' latent demands and expressed needs. Moreover, a greater number of intelligence generation mechanisms and intelligence harvesting activities should result in a reduction in the probability of important information being missed (Cadogan, Souchon, \& Procter, 2008). Effective market orientation then depends on organisations having processes for effectively collecting market intelligence about customers and competitors and then integrating this intelligence into the strategic decision-making process (responses) of the organisation in a timely manner (Hult \& Ketchen, 2001). We suspect that intelligence generation will benefit customer performance regardless of the management mechanism employed as ultimately any response to the market is dependent on possessing information on which to base a decision.

Scholars suggest mechanisms must be in place for intelligence generated to be disseminated effectively to other parts of an organisation (Kohli \& Jaworski, 1990). 
Intelligence dissemination refers to the process and extent of market information exchange within a given organisation (Kohli, Jaworski, \& Kumar, 1993). However, how decision-makers notice, encode, interpret and focus time and effort on issues and answers that emerge from intelligence generation efforts is affected by how the person chooses to manage the information presented to them given their bounded rationality (Ocasio, 1997). Therefore, the responses of decision-makers are unlikely to be optimal because they are forced to filter the abundance of information that confronts them (Ocasio, 1997). This scenario is driven by the organisation-wide dissemination component of market orientation. Less dissemination would allow for better filtering and targeting of market intelligence to those most capable of capitalising on it; since unless market intelligence is actually put to use, little will be accomplished (Fletcher \& Wheeler, 1989); therefore this scenario would likely benefit performance. Consequently, excessive dissemination may not be good overall for the organisation, a proposition explained by the inverted U-shape presented by Cadogan, Kuivalainen and Sundqvist (2009) to explain the market orientation-performance relationship. This may serve to confuse the response needed by involving far too many parties in interpreting intelligence and wishing to factor their views into any actions to be taken, which relates to the problems of symbolic information use (Vyas \& Souchon, 2003). From our understanding of external service providers we would likely expect such a situation to be exacerbated given their propensity toward greater information and knowledge intensity relative to internally managed rivals in pursuing performance goals; as evidence, external providers have a superior level of customer information relative to internal providers, which is achieved through customer profiling primarily in order to increase income (Audit Commission, 2006). 
Unless an organisation responds to the market intelligence it generates, then ultimately very little is accomplished (Kohli \& Jaworski, 1990). Market intelligence responsiveness is an integral component of the market orientation construct for public leisure providers. The speed and coordination with which market intelligence is responded to dictates whether the organisation responds faster than its competitors and in a manner timelier to its customers (Kohli et al., 1993). An organisation's competence at designing and implementing market responses is a further component of effective responsiveness (Kohli et al., 1993). The design and execution of marketing responses entail the development or improvement of the organisation's competitive positioning and product-service offering (Souchon et al., 2004). An organisation more adept at these activities should enhance customer satisfaction and loyalty because market-oriented firms are well positioned to offer goods and services to satisfy customer needs (Slater \& Narver, 1994). The performance of an organisation therefore depends on its responsiveness to customer needs (Kohli \& Jaworski, 1990).

Market orientation is very much a market-driven culture that stresses the importance of thorough market intelligence processing and the necessity of functionally coordinated actions directed at gaining a competitive advantage (Day, 1994). The two distinguishable providers of service delivery, internal and external, are likely then to result in different effects from market orientation, not in the direction of the relationships but in the strength of the hypothesised relationships. Internal providers are subject to constraints from local government, more bureaucratic by nature, comprising many formal routines, mechanistic structures, complicated communication channels, many external stakeholders, conflicting environmental demands, and low managerial autonomy (e.g., 
Brewer \& Lam, 2009) and as a result of such conflicting demands, perspectives, and potential information sources, are less likely to be focused in their market orientation activities; as evidence, internal providers have smaller marketing budgets relative to external providers, which results in ineffective marketing and missed opportunities to increase income and address the needs of customers (Audit Commission, 2006). Consequently, we suspect that whilst market orientation elements will impact performance, these effects will be weaker relative to externally managed providers. Conversely, externally managed providers tend to be structured cross-functionally and across public-private boundaries in such ways that require cross-functional coordination mechanisms. Put simply, cross-functional and cross-boundary organisations have better connected communication channels and systems as part of their management context (McDermott et al., 2009) and this is known to enable superior market orientation (Cadogan et al., 2008). Furthermore, external providers are more focused on the creation of superior customer value and competitive advantage (Audit Commission, 2006), and market orientation is more aligned with the conditions and motivations of externally managed firms as a result (Slater \& Narver, 1995) as the marketing literature extols market orientation in pursuit of such goals (Slater \& Narver, 1995; Narver \& Slater, 1990). Accordingly, we expect market orientation to have stronger performance effects for externally managed providers than internally managed rivals.

Hypothesis 1: Intelligence generation is positively related to customer performance but this effect is (a) weaker for internal service providers and (b) stronger for external service providers. 
Hypothesis 2: Organisation-wide intelligence dissemination is negatively related to customer performance but this effect is (a) weaker for internal service providers and (b) stronger for external service providers.

Hypothesis 3: Responsiveness is positively related to customer performance but this effect is (a) weaker for internal service providers and (b) stronger for external service providers.

\section{The Moderating Role of Absorptive Capacity}

Market orientation resembles a learning process in which organisations acquire external knowledge from their environment, customers, and competitors to inform current and future product-service provisions (Grewal \& Tansuhaj, 2001; Kohli \& Jaworski, 1990). Market oriented organisations then derive performance benefits from this influx of knowledge and the responses to this knowledge (Slater \& Narver, 1995). As absorptive capacity reflects the enhanced learning ability which follows from a higher stock of existing knowledge in a given domain, it is likely then that market orientation will benefit from an enhanced absorptive capacity and the relationship with performance should benefit likewise. However, market orientation also generates increasingly greater quantities of intelligence in time, which begins to capture the information problem at the heart of market orientation. As the amount of knowledge acquired from sources grows, managers and decision-makers become increasingly overloaded with information, compromising the quality and effectiveness of market response in turn (Vyas \& Souchon, 2003), as they become increasingly incapable of filtering and managing the information at hand (Ocasio, 1997). 
Absorptive capacity operates as a filtering mechanism to assimilate and retain only knowledge that is deemed relevant to the lessons the organisation has learnt from the past, transforming these knowledge bundles into increasingly valuable knowledge stocks (Garud \& Nayyar, 1994), which in turn can affect firm performance (Murray et al., 2009). As the organisation and its employees become increasingly better experienced at exploring, transforming and exploiting knowledge, its ability to capitalise more effectively and more quickly on knowledge acquired through market orientation should improve (Baker \& Sinkula, 1999; Lichtenthaler, 2009). Taken together, the quality of the organisation's responses to market intelligence should increase when its absorptive capacity is strong, thereby improving its customer performance.

Hypothesis 4: Absorptive capacity positively moderates the relationship between responsiveness and customer performance for public leisure providers.

\section{Research Method}

Using a mail survey approach, this study targeted the entire population of local government-owned leisure facilities in England sourced from The Leisure Database (TLDCi). In total, 1,060 questionnaires were mailed to public leisure facility managers nationally; of this target population, 540 facilities were internally managed and 520 facilities were externally managed. The survey instrument follows the recommendations, directions and principles of good questionnaire development practice set forth by Dillman (2007).

An overall useable response rate of 26\% (280) was achieved, representing a quarter of the population, with a consistent representation of internal (152) and external 
(128) service providers. Non-response bias was examined by performing a respondentnon-respondent comparison on a random sample of 100 respondents and 100 nonrespondents following the directions of Morgan, Vorhies and Mason (2009) and Hughes, Hughes and Morgan (2010). We examined for significant differences between these public leisure service providers using objective data on adult membership numbers and 'pay \& play’ cost. No significant differences were found between respondents and nonrespondents for adult membership ( $F=.129$; ns) and 'pay \& play' cost $(F=2.126$; ns).

\section{Measures}

Market orientation is assessed through the use of the MARKOR scale developed and validated by Kohli et al. (1993). This is a suitable tool for measuring the market orientation components of intelligence generation, dissemination, and responsiveness and is commonly used in marketing research (Kara, Spillan, \& DeShields, 2004). However, Kohli et al. (1993) describe a number of shortcomings of their own scale, suggesting that it may be too long and consist of items relating to specific activities that may not be generalisable to public organisations. Thus, this study adopts a modified version of this scale. MARKOR scale items referring to different departments, which relate to specific organisational activities and structure that are consistent with private sector organisations but are not generalisable to public leisure service providers, were excluded from the final measurement scale used (e.g., 'Several departments get together periodically to plan a response to changes taking place in our business environment'; 'The activities of the different departments in this business unit are well coordinated').

Organisations place different emphasis on routines, processes and activities to learn lessons from acquired knowledge and past use of knowledge in their activities. It is 
on this basis that organisations vary in their absorptive capacity (Cohen \& Levinthal, 1990; Zahra \& George, 2002). To capture this, measurement items were drawn from the work of Calantone, Cavusgil and Zhao (2002). These scales were appropriate as they reflect an organisation's efforts to build an absorptive capacity and to transform acquired knowledge into valuable learning outcomes. Specifically the items captured the presence of formal activities, systems and processes to capture and assimilate lessons from the acquisition and use of knowledge over time, events, and so forth.

Performance was assessed from the vantage point of customers, comprising conventional perceptual measures of customer satisfaction, customer value, the quality of services and the development of services. This is particularly appropriate since public leisure services are ultimately competing for a share of customers against private leisure facilities. The satisfaction of these users is therefore paramount to securing and maintaining market share. A 7-point Likert-type scale was adopted for all items to improve reliability and for ease of response and administration. Performance measures were scaled as (1) very poor to (7) excellent when comparing performance over the past three years to that of other competing public leisure service providers.

\section{Reliability and Validity}

Content validity was determined by distributing the questionnaire to several academics that had substantial knowledge of the literature from which the constructs were derived. Consequently, being able to comment on the degree to which the measures used capture the aforementioned constructs. Similarly, distributing the questionnaire to several public leisure managers, with the objective to ensure that the measures employed were appropriately worded and understood by the respondents, assessed face validity. The 
feedback given by academics and public leisure managers was then used to enhance and modify the research questionnaire to ensure content and face validity of the measures.

All measures were subjected to confirmatory factor analysis (CFA). Measurement item properties are detailed in Table 2 and descriptive statistics can be found in Table 3. The model fit results (LISREL 8.8, maximum likelihood estimation, covariance matrix) demonstrate acceptable fit $\left(\chi^{2}=223.14 ; \mathrm{df}=125\right.$; RMSEA $=.05$; CFI $=.97$; IFI $=.97$; NNFI $=.96$; GFI $=.92)$. All reliability values are above accepted thresholds. Convergent validity is demonstrated as the path coefficients from each measurement item to their respective latent variable are statistically significant as all items load significantly. Whilst some items have lower loading values we retain them as good practice for maintaining the full spectrum of results. The square root of average variance extracted for each construct exceed the correlation values between that construct and all other constructs (Table 3), and so confirms discriminant validity (Hughes, Morgan, \& Kouropalatis, 2008).

\section{Common Method Variance (CMV)}

A single source self-report questionnaire was used to generate data in this study. To protect against CMV, in developing the instrument, the directions of Spector and Brannick (1995) were followed: measurement scales were placed in random order; nonidealised responses and wording neutrality were adopted; questionnaire length was short (3 pages); and detailed instructions for completion were provided. Statistical tests for CMV through Harman's one-factor approach using CFA (Podsakoff, Mackenzie, Lee, \& Podsakoff, 2003) revealed poor model fit when a single factor was specified $\left(\chi^{2}=\right.$ 1267.76; $\mathrm{df}=152$; Root Mean Square Error of Approximation = .16; Comparative Fit 
Index = .78; Incremental Fit Index $=.78$; Non-Normed Fit Index $=.75$; Goodness-of-Fit Index $=.67)$. The $\chi^{2} / \mathrm{df}$ ratio exceeds the accepted $\leq 2.00$ cutoff; RMSEA far exceeds the acceptable cutoff of .08; and the model fit statistics also show significant problems with the single factor solution and demand its rejection (Hughes et al., 2010). We do not believe that CMV affect or underlie our data. To further rule out the possibility of CMV affecting the underlying variance in the data, a marker variable test was conducted (Lindell \& Whitney, 2001). This test assesses error attributable to CMV by estimating and accounting for a common method-related correction. A marker variable is one that is not theoretically related to all other measures in a study. In our case we identified respondent years of working experience as our marker variable. In each case, nonsignificant correlations $(p>.05)$ were found between this marker variable and the study variables. Normally the marker variable test is based upon correlation, but this is an incorrect manner of assessing CMV as any bias attributable to common method would affect the variance and covariance between items and constructs and so it is much more important to focus in on this. Thus, a more robust examination of CMV should examine how much of the covariance between variables is affected by the common method as this is what would be directly affected by CMV and is what underlies analysis within LISREL 8.8 (using maximum likelihood estimation) of relationships between latent variables. Therefore, we assessed CMV by calculating the average covariance by summing the covariance difference between the marker variable and all study variables and then dividing by the number of variables. Based on this average marker variable variance $\left(r_{\mathrm{m}}\right)$, we specified the CMV-adjusted covariance $\left(r_{\mathrm{a}}\right)$ between all the measures in the study using the following equation: 


$$
r_{\mathrm{a}}=\left(r_{\mathrm{u}}-r_{\mathrm{m}}\right) /\left(1-r_{\mathrm{m}}\right)
$$

Where:

$r_{\mathrm{a}}=\mathrm{CMV}$-adjusted covariance

$r_{\mathrm{u}}=$ original covariance

$r_{\mathrm{m}}=$ marker variable covariance

The modified covariance matrix was then used in LISREL 8.8 by respecifiying the original covariance matrix in the original CFA model to the new CMV-adjusted matrix to examine the effects of CMV on the data. In this case, the results indicated that with CMV-adjusted covariance, the changes in the measurement model were nonsignificant as the substitution did not significantly deteriorate fit $\left(\Delta \chi^{2}=1.11 ; \Delta \mathrm{df}=0\right.$; $\Delta \mathrm{CFI}=.01$ [reduction]; no changes to NNFI, IFI and GFI). Whilst CMV cannot be entirely excluded, the results of these CMV tests indicate that such a bias does not appear to be a threat within our data and is unlikely to explain the relationships found between the study variables (Podsakoff et al., 2003).

\section{Analysis and Results}

Since we are investigating two different contexts, two sets of descriptive statistics are required; these are presented in Table 1 . The findings suggest that there is no significant correlation between intelligence generation and customer performance for internal providers. On the other hand, there is no significant correlation between dissemination and responsiveness, or dissemination and customer performance for external providers. This analysis provides an early indication of the kind of association between study variables while accounting for management context, but is employed as a precursor to more extensive hypothesis testing through structural equation modelling (SEM) analysis. 


\section{...Insert Table 1 here...}

Interaction terms were created following the prescriptions of Ping (1995). Items involved in interactions terms were summated and then mean-centred and equations developed by Ping (1995) were employed to determine the factor loadings and error variances of each moderator so that these could then be used in structural equation modelling. Multigroup SEM was employed to test the hypotheses using LISREL 8.8. We split the sample by management type with the first consisting of internally managed service providers and the second consisting of the externally managed service providers. Two structural models were specified. The first model was a restricted model in which the $\gamma$ parameters linking market orientation and the moderators to performance for the second group were fixed at zero, and the $\gamma$ parameters for first group were freely estimated. The second model was an unrestricted model in which those $\gamma$ parameters originally fixed at zero were freed. For the restricted model, the fit statistics were $\chi^{2}$ (df) $=310.13(170) ;$ RMSEA $=.08 ;$ CFI $=.92 ; \mathrm{IFI}=.92 ; \mathrm{NNFI}=.90$. For the unrestricted model, the fit statistics were $\chi^{2}(\mathrm{df})=304.32(168)$; RMSEA $=.08$; CFI = .92; IFI = .93; NNFI $=.90$. Moving from the restricted model to the unrestricted model resulted in a decrease in $\chi^{2}$ of 5.81, with an associated decrease of 2 degrees of freedom. This change in $\chi^{2}$ is an improvement in fit significant at $p \leq .05$ and indicates that the unrestricted model is superior and most appropriate to use in hypothesis testing (Hughes et al., 2010). The SEM results are presented in Table 4.

Examination of the results for internal service providers reveals mixed support for $\mathrm{H}_{1}$ : intelligence generation is positively related to performance for external providers whilst a negative relation is found for internal providers, which refutes H1a $(\gamma=-.22$; $p \leq$ 
.05). As expected however, the relationship is stronger for external providers and confirms H1b $(\gamma=.28 ; p \leq .01)$. Dissemination is found to have a negative effect on performance for external providers but this is statistically non-significant $(\mathrm{H} 2 \mathrm{~b} ; \gamma=-.11$; ns), but it does however have positive performance implications for internal providers and again refutes H2a $(\gamma=.40 ; p \leq .10)$. H3 is completely supported as responsiveness relays positive performance implications for both internal $(\gamma=.59 ; p \leq .01)$ and external providers $(\gamma=.42 ; p \leq .01)$, and is stronger for external providers $(t=3.30 ; p \leq .01)$.

Results for the moderating role of absorptive capacity paint an interesting picture. Absorptive capacity does positively moderate the relationship between responsiveness and performance $(\gamma=.16 ; p \leq .01)$ for internal service providers and supports H4. In relation to external providers the results show that responsiveness when moderated by absorptive capacity no longer positively influences customer performance as this moderating relationship is negative $(\gamma=-.14 ; t=-.76)$ but, crucially, is non-significant. Absorptive capacity would then appear to have mixed influences on responsiveness and performance in different contexts.

\section{...Insert Tables 2, 3 and 4 here...}

\section{Discussion and Implications}

The objective of this study was to examine the market orientation-performance relationship by focusing attention on the role of absorptive capacity and management context of public sector leisure service providers. Our contribution to marketing theory is two-fold. First, and to the best of our knowledge, we are the first to account for the effect of market orientation on the customer performance of public service organisations while simultaneously accounting for management contexts, specifically, internal and external 
providers. Dissemination and responsiveness benefit customer performance for internally managed public leisure organisations. For externally managed leisure organisations, market orientation has a more dramatic effect on performance with intelligence generation and response eliciting positive implications for performance but excessive dissemination of intelligence counteracts this. Our findings are supportive of the stance taken by marketing scholars over the broad applicability of this marketing concept.

Second, and to the best of our knowledge, this is the first study to test the impact of absorptive capacity on the market orientation-performance interface across management context. We contribute to the theoretical and empirical development of market orientation by finding that absorptive capacity can moderate the intelligence responsiveness-customer performance relationship. For internally managed public leisure organisations absorptive capacity does strengthen the effect of response on performance as positive moderation was found. However, for externally managed public leisure organisations, absorptive capacity weakens the effect of response on performance as a negative non-significant moderation was found. Absorptive capacity may then explain how firms generate unique advantages from their market orientation. This requires further and broader empirical analysis in both the public and private sector.

\section{Theoretical Implications}

With respect to our first contribution, our findings are consistent with Crompton (2008) in that we argue that a market orientation is appropriate for public leisure service agencies. The market orientation construct is found to have positive effects on customer performance outcomes for public leisure provision. We show that public service provision can benefit from assimilating marketing constructs traditionally associated with 
private sector firms. For marketing scholars, the theory of the marketing concept traditionally operationalised by market orientation appears increasingly universal. In turn, such a conclusion carries the need to better specify how market orientation might behave in different contexts, what factors underpin its success and how marketing assets subsequently develop. With respect to our second contribution, we find that absorptive capacity does affect the market orientation responsiveness-performance relationship across management context, which suggests the need to theoretically examine and reevaluate this construct. These findings provide important theoretical implications. First, though marketing scholars have begun to consider the role of absorptive capacity in the market-orientation-performance interface, herein we demonstrate its importance to properly specify and understand the benefits of marketing's principle construct, market orientation. Market orientation can inundate an organisation with information and so an inadequate absorptive capacity can lead to insufficient knowledge being dissected from that information overload to inform and enable effective market decision-making. In turn, marketing scholars should be increasingly vigilant to lessons from organisational learning theory to better inform marketing theory development and marketing practice. The future of market orientation research likely lies outside the confines of marketing theory alone. Second, we speculated in our theoretical development that information-laden organisations (i.e., those with a market orientation) with complex structures would be expected to suffer information transfer problems and information management difficulties brought about by information overload. Thus, the value of absorptive capacity on the market orientation-performance relationship may well differ by the complexity of the 
management context. Theory however has not specified what sort of complex management context might affect the relationship.

Internal and external management of service provisions although 'complex' are complex for different reasons. Internal providers are notoriously bureaucratic comprising many formal routines, mechanistic structures and complicated communication channels (e.g., Brewer \& Lam, 2009). External providers are complex because they tend to be structured cross-functionally and cross public-private boundaries in a manner requiring coordination mechanisms in turn (McDermott, Corredoira, \& Kruse, 2009). Studies into market orientation have long reported on the favourability of cross functional conditions (e.g., Cadogan et al., 2008), which helps to explain the moderation effect of absorptive capacity on the intelligence responsiveness-performance relationship for external provision. Put simply, cross-functional and cross-boundary organisations have better connected communication channels and systems as part of their management context (McDermott et al., 2009); while bureaucratically complex organisations have less natural (or realised) absorptive capacity, hence the need to build one (Jansen et al., 2005; Yeoh, 2009), but such firms can benefit from a capable absorptive capacity to improve knowledge transfer and usage (Chen et al., 2009; Ocasio, 1997). We demonstrate empirically how context does indeed vary the effect of, and need for, absorptive capacity in organisations.

For marketing scholars, market orientation theory should take into account the learning processes prevalent in organisations both from its management and structural context and in terms of formal capabilities. The market orientation-performance relationship risks being underspecified if such conditions are not accounted for. Thus, our 
findings extend models of market orientation with new and important conditions. The study of market orientation has been extended to understand the role of resources (Morgan et al., 2009), learning (Baker \& Sinkula, 2005) and information load (Souchon et al., 2004; Vyas \& Souchon, 2003) culminating from calls to identify mediators and moderators of its relationship with performance (Langerak, 2003). We add absorptive capacity and management context to this debate and show how important these are to understand market orientation theory in different organisations. Marketing scholars should assimilate these in future specifications of market orientation and look to extend further our knowledge of learning processes and management context for marketing theory and practice.

\section{Practice-based Implications}

Fenwick and McMillan (2005) suggest that the unique knowledge (of the community and of the shared social goals as well as the 'product' or service) possessed by local government (or internal providers) differentiates it from external provision. Therefore, external providers can be assumed to view the organisation of knowledge in a different way to that of internal providers; since different networks value knowledge in different ways (Fenwick \& McMillan, 2005). Internal providers can benefit from carefully manipulating organisational absorptive capacity and its response to intelligence, which is enhanced through its capacity to recognise and combine market oriented intelligence with its unique knowledge base on community needs (that is, using its market orientation effectively with its absorptive capacity for existing, new, and future knowledge). Combining different matrices of knowledge (unique knowledge on the community with externally acquired customer knowledge) depends on the strength of the organisation's 
absorptive capacity. Often, partnerships in the form of external providers do not possess such unique knowledge as the local government brings little more than a facilitating role to these partnerships. Coordination mechanisms are an inherent characteristic of partnership arrangements to instigate a process of recombining the resources and information of better-placed actors with local government. This contrast helps to explain why an effective absorptive capacity is less important to benefitting from market orientation in such a context.

\section{Conclusions, Limitations and Future Research}

This study is not without its limitations. First, this study was based on a cross-sectional design, and only allows causal inferences to be made from the data. We cannot make assertions about causality. Second, this study sampled public leisure providers in England. As government structures, service delivery, and resource allocation systems differ between sectors and countries, caution should be exercised against generalising the results to markedly different populations. Third, judgements about customer performance, although qualified, have been reported by a single informant and may not sufficiently capture the multi-faceted aspect of this construct, especially for public service providers. Furthermore, we did not assess customer performance from the perspective of the customer. That is, we did not gather the views of each facility's customers on the various dimensions assessed. Naturally however, this does provide options for future research in this area, for example, if the study were to be replicated or expanded into areas such as service quality. 
Our research has demonstrated the importance of market orientation for the performance of public sector leisure organisations. Leisure is an arm of the public sector that has consistently been outward facing owing to its intimate interaction with customers. Future research should expand to other arms of the public sector, particularly those not traditionally interfacing regular with customers and users, to garner further knowledge on the application of market orientation in public industries. Moreover, we show how the effects of market orientation can depend on absorptive capacity, the management and structural context of the service provision, or both. Further research is needed to study these issues in private organisations given that these concepts are not unique to public organisations, just as market orientation is not unique to private ones. This should be of immediate concern given the findings relating to absorptive capacity. A rich stream of research opportunities is present to explore the nature of market orientation across public and private organisations therefore. We also note the need to better understand the conditions under which market orientation is implemented. Not all components of this orientation are necessarily universally positive and moderation effects can change the nature of the relationship between components of market orientation and performance. As such, treating market orientation as a higher order construct in statistical analyses may introduce confounding effects or misleading results and accordingly we caution researchers from taking such an approach when examining market orientation. In a similar vein, treating market orientation as a universally positive notion is not necessarily correct as context clearly had an impact on which aspects of market orientation were good or dangerous to performance. This does not mean advocating using only some aspects of market orientation, but rather, the discovery of moderators that 
inhibit the potentially negative or damaging aspects of market orientation. We studied absorptive capacity as an organisation level construct but some of the mechanisms that explain its relevance to the interface between intelligence responsiveness and customer performance point to individual level issues. For example, how might managers cope with the information fed to them by the organisation's market orientation? What are the specific challenges faced by marketing decision-makers when facing intelligence responsiveness challenges under conditions of high information load? Qualitative studies may help shed light on the theory implications of these issues.

In conclusion, market orientation is important within the public sector and does confer differential benefits for internally and externally managed public service providers but it is important not to consider it in isolation and understand the effects of learning mechanisms such as absorptive capacity on its influence on the organisation. 


\section{References}

Argote, L., McEvily, B., \& Reagans, R. (2003). Managing knowledge in organizations: an integrative framework and review of emerging themes. Management Science, 49, 571-582.

Audit Commission (2006). Public sports and recreation services: making them fit for the future, Audit Commission for Local Authorities and the National Health Service in England: Local Government National Report, June.

Baker, W.E., \& Sinkula, J.M. (1999). The synergistic effect of market orientation and learning orientation on organizational performance. Journal of the Academy of Marketing Science, 27, 411-427.

Berg, E.B., Barry, J.J., and Chandler, J.P. (2008). New public management and social work in Sweden and England. International Journal of Sociology and Social Policy, 28, 114-128.

Butler, P., \& Collins, N. (1995). Marketing public sector services: concepts and characteristics. Journal of Marketing Management, 11(1/3), 83-96.

Brewer, B., \& Lam, G.K.Y. (2009). Conflict handling preferences: a public-private comparison. Public Personnel Management, 38, 1-14.

Cadogan, J., Kuivalainen, O., \& Sundqvist, S. (2009). Export market-oriented behaviour and export performance: quadratic and moderating effects under differing degrees of market dynamism and internationalisation. Journal of International Marketing, 17, 71-89.

Cadogan, J.W., Souchon, A.L., \& Procter, D.B. (2008). The quality of market-oriented behaviors: formative index construction. Journal of Business Research, 61, 12631277.

Caemmerer, B., \& Banerjee, M. (2009). An exploration of assimilating service relation strategies in the private and the public sector. Journal of Relationship Marketing, 8, 68-79.

Calantone, R.J., Cavusgil, S.T., \& Zhao, Y. (2002). Learning orientation, firm innovation capability, and firm performance. Industrial Marketing Management, 31, 515524.

Cano, C.R., \& Sams, D. (2009). The importance of an internal marketing orientation in social services. International Journal of Nonprofit and Voluntary Sector Marketing, 14, 285-295.

Caruana, A., Ramaseshan, B., \& Ewing, M.T. (1999). Market orientation and performance in the public sector. Journal of Global Marketing, 12, 59-79.

Cervera, A., Molla, A., \& Sanchez, M. (2001). Antecedents and consequences of market orientation in public organisations. European Journal of Marketing, 35, 12591288.

Chen, Y.-S., Lin, M.-J.J., \& Chang, C.-H. (2009). The positive effects of relationship learning and absorptive capacity on innovation performance and competitive advantage in industrial markets. Industrial Marketing Management, 38, 152-158.

Cohen, W.M., \& Levinthal, D.A. (1990). Absorptive capacity: a new perspective on learning and innovation. Administrative Science Quarterly, 35, 128-152.

Crompton, J.L. (2008). Evolution and implications of a paradigm shift in the marketing of leisure services in the USA. Leisure Studies, 27, 181-206. 
Day, G.S. (1999). The Market-Driven Organization. New York, NY: The Free Press.

Dickson, P.R., (1996). The static and dynamic mechanics of competition: a comment on Hunt and Morgan's comparative advantage theory. Journal of Marketing, 60, 102106.

Dillman, D.A., (2007). Mail and Internet Surveys: The Tailored Design Method. John New Jersey, NJ: Wiley and Sons.

Fenwick, J., \& McMillan, J. (2005). Organisational learning and public sector management: an alternative view. Public Policy and Administration, 20, 42-55.

Fletcher, K., \& Wheeler, C. (1989), Market intelligence for international markets. Marketing Intelligence \& Planning, 7, 30-34.

Friend, J. (2006). Partnership meets politics: managing within the maze. International Journal of Public Sector Management, 19, 261-277.

Garud, R., \& Nayyar, P.R. (1994). Transformative capacity: continual structuring by intertemporal technology transfer. Strategic Management Journal, 15, 365-385.

Grewal, R., \& Tansuhaj, P. (2001). Building organizational capabilities for managing economic crisis: the role of market orientation and strategic flexibility. Journal of Marketing, 65, 67-80.

Huber, G.P. (1991). Organizational learning: the contributing processes and the literature. Organization Science, 2(1), 88-115.

Hughes, P., Hughes, M., \& Morgan, R.E. (2010). Why do product-market strategies fail? A sociostructural examination under conditions of adherence. Group \& Organization Management, 35, 606-635.

Hughes, P., Morgan, R.E., \& Kouropalatis, Y. (2008). Market knowledge diffusion and business performance. European Journal of Marketing, 42, 1372-1395.

Hult, G.T.M., \& Ketchen, D.J. (2001). Does market orientation matter: a test of the relationship between positional advantage and performance. Strategic Management Journal, 22, 899-906.

Jansen, J.J.P., Van Den Bosch, F.A.J., \& Volberda, H.W. (2005). Managing potential and realized absorptive capacity: how do organizational antecedents matter?. Academy of Management Journal, 48, 999-1015.

Jaworski, B.J., \& Kohli, A.K. (1993). Market orientation: antecedents and consequences. Journal of Marketing, 57,. 53-70

Jones, C., \& Hecker, R. (2003). E-extinction: all illusion of knowledge, the presence of ignorance, or evolutionary fate? Journal of Enterprising Culture, 11, 359-378.

Kara, A., Spillan, J.E., \& DeShields, O.W. (2004). An empirical investigation of the link between market orientation and business performance in non-profit service providers. Journal of Marketing Theory and Practice, 12, 59-72.

Kirca, A.H., Jayachadran, S., \& Bearden, W.O. (2005). Market orientation: a metaanalytic review and assessment of its antecedents and impact on performance. Journal of Marketing, 69, 24-41.

Kogut, B., \& Zander, U. (1992). Knowledge of the firm, combinative capabilities, and the replication of technology. Organization Science, 3, 383-397.

Kohli, A.K., \& Jaworski, B.J. (1990). Market orientation: the construct, research propositions, and managerial implications. Journal of Marketing, 54, 1-18.

Kohli, A.K., Jaworski, B.J., \& Kumar, A. (1993). MARKOR: a measure of market orientation. Journal of Marketing Research, 30, 467-477. 
Laing, A. (2003). Marketing in the public sector: towards a typology of public services. Marketing Theory, 3, 427-445.

Laffin, M., \& Liddle, J. (2006). New perspectives on partnership. International Journal of Public Sector Management, 19, Editorial.

Lane, P.J., Koka, B., \& Pathak, S. (2006). The reification of absorptive capacity: a critical review and rejuvenation of the construct. Academy of Management Review, 31, 833-863.

Langerak, F. (2003). An appraisal of research on the predictive power of market orientation. European Management Journal, 21, 447-464.

Lichtenthaler, U. (2009). Absorptive capacity, environmental turbulence, and the complementarity of organizational learning processes. Academy of Management Journal, 52, 822-846.

Lindell, M.K., \& Whitney, D.J. (2001). Accounting for common method variance in cross-sectional research designs. Journal of Applied Psychology, 86, 114-121.

Macedo, I.M., \& Pinho, J.C. (2006). The relationship between resource dependence and market orientation. European Journal of Marketing, 40, 533-553.

McDermott, G.A., Corredoira, R.A., \& Kruse, G. (2009). Public-private institutions as catalysts of upgrading in emerging market societies. Academy of Management Journal, 52, 1270-1296.

McDonald, R.E., \& Madhavaram, S. (2007). What firms learn depends on what firms know: the implications of prior knowledge for market orientation. The Marketing Management Journal, 17(1), 171-183.

Morgan, N.A., Vorhies, D.W., \& Mason, C.H. (2009). Market orientation, marketing capabilities, and firm performance. Strategic Management Journal, 30, 909-920.

Murray, J.Y, Kotabe, M., \& Westjohn, S.A. (2009). Global sourcing strategy and performance of knowledge-intensive business services: a two-stage strategic fit model. Journal of International Marketing, 17, 90-105.

Narasimhan, O., Rajiv, S., \& Dutta, S. (2006). Absorptive capacity in high-technology markets: the competitive advantage of the haves. Marketing Science, 25, 510-524.

Narver, J.C., \& Slater, S.F. (1990). The effect of a market orientation on business profitability. Journal of Marketing, 36, 20-35.

Nelson, L., \& Henderson, S. (2005). Best value and the market orientation of UK recreation centres. Local Government Studies, 31, 237-257.

Navatorov, E.V., \& Crompton, J.L. (2001). A revised conceptualisation of marketing in the context of public leisure services. Journal of Leisure Research, 33, 160-185.

Ocasio, W. (1997). Towards an attention-based view of the firm. Strategic Management Journal, 18(S1), 187-206.

Olavarrieta, S., \& Friedman, R. (2008). Market orientation, knowledge-related resources and firm performance. Journal of Business Research, 61, 623-630.

Ping, R.A. (1995). A parsimonious estimation technique for interaction and quadratic latent variables. Journal of Marketing Research, 32, 336-347.

Peters, B. (1998). With a little help from our friends: public-private partnerships as institutions and instruments. In J. Pierre (Ed.). Partnerships in Urban Governance (pp. 1-10). London: Macmillan. 
Pitt, L., Caruana, A., \& Berthon, P.R. (1996). Market orientation and business performance: some European evidence. International Marketing Review, 13(1), 518.

Podsakoff, P.M., MacKenzie, S.B., Lee, J., \& Podsakoff, N.P. (2003). Common method biases in behavioral research: A critical review of the literature and recommended remedies. Journal of Applied Psychology, 88, 879-903.

Reid, G. (2003). Charitable trusts: municipal leisure's third way?. Managing Leisure, 8, 171-183.

Shoham, A., Ruvio, A., Vigoda-Gadot, E., \& Schwabsky, N. (2006). Market orientations in the nonprofit and voluntary sector: a meta-analysis of their relationships with organisational performance. Nonprofit and Voluntary Sector Quarterly, 35, 453476.

Slater, S.F. \& Narver, J.C. (1994). Market orientation, customer value, and superior performance. Business Horizons, 37, 22-28.

Slater, S.F., \& Narver, J.C. (1995). Market orientation and the learning organization. Journal of Marketing, 59, 63-74.

Slater, S.F., \& Narver, J.C. (1998). Customer-led and market-orientated: let's not confuse the two. Strategic Management Journal, 19, 1001-1006.

Souchon, A.L., Cadogan, J.W., Procter, D.B., \& Dewsnap, B. (2004). Marketing information use and organisational performance: the mediating role of responsiveness. Journal of Strategic Marketing, 12, 231-242.

Spector, P.E., \& Brannick, M.T. (1995). The nature and effects of method variance in organizational research. In C.L. Cooper \& I.T. Robertson (Eds.). International Review of Industrial and Organizational Psychology 10 (pp. 249-274). Chichester: Wiley.

Vyas, R., \& Souchon, A.L. (2003). Symbolic use of export information: a multidisciplinary approach to conceptual development and key consequences. International Marketing Review, 20(1), 67-94.

Walsh, J.P., \& Ungson, G.R. (1991). Organizational memory. Academy of Management Review, 16(1), 57-91.

Yeoh, P.-L. (2009). Realized and potential absorptive capacity: understanding their antecedents and performance in the sourcing context. Journal of Marketing Theory \& Practice, 17(1), 21-36.

Zahra, S.A., \& George, G. (2002). Absorptive capacity: a review, reconceptualization, and extension. Academy of Management Review, 27, 185-203. 


\begin{tabular}{|c|c|c|c|c|c|c|}
\hline \multicolumn{7}{|c|}{ Table 1. Descriptive statistics } \\
\hline \multirow{8}{*}{$\begin{array}{c}\text { Service } \\
\text { Provision } \\
\text { Internal }\end{array}$} & & 1. & 2. & 3. & 4. & 5. \\
\hline & 1. Intelligence Generation & & & & & \\
\hline & 2. Intelligence Dissemination & $.37 * *$ & & & & \\
\hline & 3. Responsiveness & $.28^{* *}$ & $.48^{* *}$ & & & \\
\hline & 4. Absorptive Capacity & $.40^{* *}$ & $.54^{* *}$ & $.35^{* *}$ & & \\
\hline & 5. Customer Performance & $.13 \mathrm{~ns}$ & $.34 * *$ & $.47 * *$ & $.32 * *$ & \\
\hline & Mean & 5.65 & 4.64 & 5.41 & 4.52 & 5.28 \\
\hline & SD & 1.29 & 1.57 & 1.06 & 1.32 & .95 \\
\hline \multirow[t]{7}{*}{ External } & 1. Intelligence Generation & & & & & \\
\hline & 2. Intelligence Dissemination & $.36^{* *}$ & & & & \\
\hline & 3. Responsiveness & $.31^{* *}$ & $.11 \mathrm{~ns}$ & & & \\
\hline & 4. Absorptive Capacity & $.31 * *$ & $.32 * *$ & $.29 * *$ & & \\
\hline & 5. Customer Performance & $.33^{* *}$ & $.04 \mathrm{~ns}$ & $.37 * *$ & $.33 * *$ & \\
\hline & Mean & 5.76 & 4.95 & 5.69 & 4.74 & 5.36 \\
\hline & SD & 1.25 & 1.45 & .93 & 1.07 & .90 \\
\hline
\end{tabular}

Notes: $\quad * * \mathrm{p}<.01$.

SD: Standard deviation.

ns: Non-significant 


\begin{tabular}{|c|c|c|c|}
\hline \multicolumn{4}{|c|}{ Table 2. Measurement item properties } \\
\hline Construct & Measurement Item & $\begin{array}{l}\text { Standardized } \\
\text { Factor Loading }\end{array}$ & t-Value \\
\hline \multirow{5}{*}{$\begin{array}{l}\text { Intelligence } \\
\text { Generation }\end{array}$} & We formally consult customers at least once a year to & & \\
\hline & $\begin{array}{l}\text { find out what products or services they will need in the } \\
\text { future }\end{array}$ & 84 & 15.21 \\
\hline & $\begin{array}{l}\text { We gather data from our sector for use in the } \\
\text { developmental plans for our activities }\end{array}$ & .70 & 12.19 \\
\hline & We survey customers at least once a year to assess the & & \\
\hline & quality of our products and services & .78 & 13.95 \\
\hline \multirow{3}{*}{$\begin{array}{l}\text { Intelligence } \\
\text { Dissemination }\end{array}$} & We have meetings at least once a quarter to discuss & & \\
\hline & $\begin{array}{l}\text { market trends and developments } \\
\text { Our facility periodically circulates documents (e.g. } \\
\text { reports, newsletters) that provide information on our }\end{array}$ & .73 & 9.95 \\
\hline & customers & .60 & 8.67 \\
\hline \multirow[t]{6}{*}{$\begin{array}{l}\text { Intelligence } \\
\text { Responsiveness }\end{array}$} & $\begin{array}{l}\text { It takes us forever to decide how to respond to our } \\
\text { competitors' price changes }{ }^{(\mathrm{R})}\end{array}$ & .51 & 7.80 \\
\hline & $\begin{array}{l}\text { For one reason or another we tend to ignore changes in } \\
\text { our customers' service needs }{ }^{(\mathrm{R})}\end{array}$ & .73 & 11.98 \\
\hline & Customer complaints fall on deaf ears in this facility ${ }^{(\mathrm{R})}$ & .49 & 7.57 \\
\hline & $\begin{array}{l}\text { Even if we came up with a great marketing plan, we } \\
\text { probably would not be able to implement it in a timely } \\
\text { fashion }{ }^{(\mathrm{R})}\end{array}$ & .66 & 10.69 \\
\hline & $\begin{array}{l}\text { When we find out that customers are unhappy with the } \\
\text { quality of our service, we take corrective action }\end{array}$ & & \\
\hline & immediately & .44 & 6.62 \\
\hline \multirow{6}{*}{$\begin{array}{l}\text { Absorptive } \\
\text { Capacity }\end{array}$} & We always audit unsuccessful product-market strategy & & \\
\hline & $\begin{array}{l}\text { endeavours and communicate the lessons learned } \\
\text { Lessons learned from past product-market decisions are } \\
\text { thoroughly shared and discussed with others in the }\end{array}$ & .75 & 13.86 \\
\hline & facility & .84 & 16.37 \\
\hline & We have specific mechanisms for sharing lessons & & \\
\hline & learned in the overall product-market strategy process & 87 & 17.23 \\
\hline & $\begin{array}{l}\text { Facility conversation keeps alive the lessons learned } \\
\text { from overall product-market strategy history }\end{array}$ & 68 & 12.22 \\
\hline \multicolumn{4}{|l|}{ Customer } \\
\hline \multirow[t]{4}{*}{ Performance } & Achieving customer satisfaction & .74 & 13.23 \\
\hline & Providing value for customers & .71 & 12.36 \\
\hline & Quality of services & .78 & 14.04 \\
\hline & Development of services & .72 & 12.61 \\
\hline
\end{tabular}




\begin{tabular}{|c|c|c|c|c|c|c|}
\hline \multicolumn{7}{|c|}{ Table 3. Correlation matrix and descriptive statistics } \\
\hline & & $X 1$ & $X 2$ & $\mathbf{X 3}$ & $X 4$ & $X 5$ \\
\hline$X 1$ & Intelligence Generation & $.78^{a}$ & & & & \\
\hline$X 2$ & Intelligence Dissemination & $.36 * *$ & .67 & & & \\
\hline \multirow[t]{2}{*}{$X 3$} & Intelligence & & & & & \\
\hline & Responsiveness & $.29 * *$ & $.34 * *$ & .58 & & \\
\hline$X 4$ & Absorptive Capacity & $.34 * *$ & $.42 * *$ & $.31 * *$ & .79 & \\
\hline X5 & Customer Performance & $.22 * *$ & $.22 * *$ & $.43^{* *}$ & $.30^{* *}$ & .74 \\
\hline \multicolumn{2}{|c|}{ Mean } & 5.70 & 4.78 & 5.54 & 4.49 & 5.32 \\
\hline \multicolumn{2}{|c|}{$S D$} & 1.27 & 1.52 & 1.01 & 1.25 & .93 \\
\hline \multicolumn{2}{|c|}{ Construct Reliability (Cronbach a) } & .82 & .61 & .70 & .86 & .81 \\
\hline \multicolumn{2}{|c|}{ Composite Reliability } & .82 & .62 & .71 & .87 & .83 \\
\hline \multicolumn{2}{|c|}{ Average Variance Extracted } & .60 & .45 & .34 & .62 & .54 \\
\hline
\end{tabular}

Notes: ${ }^{\mathrm{a}}$ Square root of average variance extracted.

** Correlation is significant at the .01 level (2-tailed). 


\begin{tabular}{|c|c|c|c|c|}
\hline \multicolumn{5}{|c|}{ Table 4. Structural equation modelling results ${ }^{\mathrm{a}}$} \\
\hline $\begin{array}{c}\text { Service } \\
\text { Provision }\end{array}$ & Independent Variable & $\begin{array}{c}\text { Standardized } \\
\text { Coefficients }\end{array}$ & t-Value & $\begin{array}{c}\text { Model } \\
\text { Statistics }\end{array}$ \\
\hline \multirow[t]{6}{*}{ Internal } & Intelligence Generation & -.22 & $-1.76^{*}$ & \\
\hline & Intelligence Dissemination & .40 & $1.55^{\dagger}$ & \\
\hline & Intelligence Responsiveness & .59 & $3.12^{* *}$ & \\
\hline & Intelligence Responsiveness x Absorptive & & & \\
\hline & Capacity & .16 & $2.17 *$ & \\
\hline & Squared Multiple Correlations for Redu & Form & & .47 \\
\hline \multirow[t]{6}{*}{ External } & Intelligence Generation & .28 & $2.73 * *$ & \\
\hline & Intelligence Dissemination & -.11 & -1.18 & \\
\hline & Intelligence Responsiveness & .42 & $3.30^{* *}$ & \\
\hline & Intelligence Responsiveness x Absorptive & & & \\
\hline & Capacity & -.14 & -.76 & \\
\hline & Squared Multiple Correlations for Redu & 1 Form & & .38 \\
\hline
\end{tabular}

Notes: ${ }^{\mathrm{a}}$ Customer performance as dependent variable.

${ }^{\mathrm{b}}$ Critical $t$ values: when ${ }^{* *} p=.01$, critical $t$ value $=2.326$; when ${ }^{*} p=.05$, critical $t$ value $=1.645$; when $\dagger p=.10$, critical $t$ value $=1.282$. 